\title{
Deterministic Model on Concrete Density from Local 3/8 Gravel Influenced by Variation of Water Cement Ratios and Curing Age
}

\author{
Ode. T. ${ }^{1}$, Eluozo S. N. ${ }^{2}$ \\ ${ }^{1}$ Department of civil Engineering, Faculty of Engineering Rivers State University of Sciences and Technology Nkpolu, Port Harcourt, \\ Nigeria \\ ${ }^{2}$ Subaka Nigeria Limited, Port Harcourt, Nigeria
}

Email address:

odethankgod@gmail.com (Ode. T.), solondu2015@yahoo.com (Eluozo S. N.), Soloeluozo2013@hotmail.com (Eluozo S. N.)

To cite this article:

Ode. T., Eluozo S. N. Deterministic Model on Concrete Density from Local 3/8 Gravel Influenced by Variation of Water Cement Ratios and Curing Age. American Journal of Civil Engineering. Vol. 5, No. 2, 2017, pp. 111-118. doi: 10.11648/j.ajce.20170502.16

Received: August 23, 2016; Accepted: October 31, 2016; Published: March 4, 2017

\begin{abstract}
Concrete densities varies base on some level of mix design, several experts has express the densities of concrete using various grades of coarse aggregate in there mix design, these study are to express the behaviour of locally occurring $3 / 8$ gravel concrete also known as all in one aggregate 3/8 Aggregate gravel concrete. The development of concrete densities variation from experimental values compared with deterministic model simulation values were carried out in table and figures, from the graphical representation, fluctuation were observed in some values, while linear increase were express in some values, these fluctuation from the simulation values has also reflected the rate of concrete porosity varying at different water cement ratio and curing age, the heterogeneity of these densities from the predictive values are through variation from these porosity and mix proportions, water cement ratios variation were also observed to influenced the rate of concrete densities, the prediction of concrete densities at interval of seven day are the normal methods of monitoring concrete properties, but the developed model are predicting the increase of concrete densities at every twenty four hours, these method are new developed concept that can also be applied to predict other concrete parameters or properties.
\end{abstract}

Keywords: Deterministic Model, Concrete Density, Water Cement Ratio and Curing Age

\section{Introduction}

British techniques of concrete mix design make use of British test data; this can be applied for concrete containing fly ash or gabs [2]. None of these techniques offer the traditional curves that thoroughly express the correlation between w/c ratio and the strength by examine concretes made with chemical admixtures $[4,5]$. On the contrary HPC normally contains both pozzolanic and chemical admixtures. It has been an established fact that HPC mixes can be prepared without the use of mineral admixtures but cannot be without the chemical admixtures $[3,6,7,8,9,10,11,12,13$, and 14]. Normal concrete strength depend on mix design of $\mathrm{NSC}$, it is based primarily on the w/c ratio law first proposed by Abrams in 1918 [5]). However, to attained high strength concretes, all the mechanism of the concrete mixture should be pressed to their limits. In HPC there are numerous other factors that must be considered, thus selection of ingredients and their suitable proportions area always difficult. Also it is too expensive and time consuming to apply the traditional empirical concepts of making alternative trial mixes of all possible mixture to arrive at the optimum mix. Thus, the measures of obtainable mix design techniques that are normally adopted for designing NSC mixes may not be precisely used for designing HPC mixes [1].

\section{Governing Equation}

$$
N_{0} \frac{\partial C_{O}}{\partial z}=C_{G S} \frac{\partial C_{O}}{\partial l}+W_{C} \frac{\partial C_{O}}{\partial l}
$$

Equation (1) is solve using method of separation of variable whereby we let $\mathrm{C}(\mathrm{z}, \mathrm{l})=\mathrm{Z}(\mathrm{z}) \mathrm{L}(\mathrm{l})$. 


$$
\left[C_{G S}+W_{C}\right] \frac{L^{\prime}}{L}=\tau^{2}
$$

Therefore, we have a solution of the forms;

$$
Z=A \ell^{\frac{\tau^{2}}{N_{O}}} \text { and } L=B \ell^{\left(\frac{\tau^{2}}{C_{G S}+W_{C}}\right)}
$$

Which when combine gives equation (4) as thus;

$$
\begin{array}{r}
C_{0}(z, l)=A e^{\frac{\tau^{2}}{N_{O}}} B \ell^{\left[\frac{\tau^{2}}{C_{G S}+W_{C}}\right]} \\
C_{0}(z, l)=A B \ell^{\left[\frac{z}{N_{O}}+\frac{l}{C_{G S}+W_{C}}\right] \tau^{2}}
\end{array}
$$

\section{Material and Methods}

Base on BS 1881 part 114 of (1983) the cubes had been cured; they were dried under the laboratory temperature and weight using a weighing machine. The volume of the cube was found and the densities were obtained by dividing the mass by the volume. The generated results were subjected deterministic modeling approach, these results generated expressed mathematical equation for different densities characterized $3 / 8$ gravel on washed and unwashed $3 / 8$ aggregate gravel concrete at different curing age. The expressed equations form analytical solution through the parameters stated in nomenclature will be applied to predict the variation of densities made with locally occurring $3 / 8$ aggregate concrete at different curing time.

\section{Results and Discussion}

Results and discussion are presented in tables including graphical representation of predictive values for density of concrete made with locally occurring $3 / 8$ aggregate gravel.

Table 1. Predictive Values of Concrete Density at Different Curing Age.

\begin{tabular}{ll}
\hline Curing Age [Days][0.45] & Density of Concrete $\left[\mathbf{k g m}^{3}\right]$ \\
\hline 7 & 2168.93 \\
8 & 2173.73 \\
9 & 2178.54 \\
10 & 2183.36 \\
11 & 2188.18 \\
12 & 2193.02 \\
13 & 2202.73 \\
14 & 2207.6 \\
15 & 2212.48 \\
16 & 2217.37 \\
17 & 2222.28 \\
18 & 2222.28 \\
19 & 2227.19 \\
20 & 2232.12 \\
21 & 2237.05 \\
22 & 2242 \\
23 & 2246.96 \\
24 & 2251.92 \\
25 & 2256.9 \\
\hline
\end{tabular}

\begin{tabular}{ll}
\hline Curing Age [Days][0.45] & Density of Concrete $\left[\mathrm{kgm}^{3}\right]$ \\
\hline 26 & 2261.89 \\
27 & 2266.9 \\
28 & 2271.91 \\
\hline
\end{tabular}

Table 2. Predictive and Experimental Values for Concrete Density at Different Curing Age.

\begin{tabular}{lll}
\hline $\begin{array}{l}\text { Curing Age [Days] } \\
{[\mathbf{0 . 4 5}]}\end{array}$ & $\begin{array}{l}\text { Predictive Values } \\
{\left[\mathbf{k g m}^{\mathbf{3}}\right]}\end{array}$ & $\begin{array}{l}\text { Experimental Values } \\
{\left[\mathbf{k g m}^{\mathbf{3}}\right]}\end{array}$ \\
\hline 7 & 2168.93 & 2169.83 \\
8 & 2173.73 & 2174.67 \\
9 & 2178.54 & 2179.52 \\
10 & 2183.36 & 2184.3 \\
11 & 2188.18 & 2189.2 \\
12 & 2193.02 & 2194.09 \\
13 & 2202.73 & 2198.84 \\
14 & 2207.6 & 2203.67 \\
15 & 2212.48 & 2208.51 \\
16 & 2217.37 & 2213.34 \\
17 & 2222.28 & 2218.18 \\
18 & 2222.28 & 2223.01 \\
19 & 2227.19 & 2227.84 \\
20 & 2232.12 & 2232.68 \\
21 & 2237.05 & 2237.51 \\
22 & 2242 & 2242.34 \\
23 & 2246.96 & 2247.18 \\
24 & 2251.92 & 2252.02 \\
25 & 2256.9 & 2256.85 \\
26 & 2261.89 & 2261.68 \\
27 & 2266.9 & 2266.51 \\
28 & 2271.91 & 2271.35 \\
\hline
\end{tabular}

Table 3. Predictive Values of Concrete Density at Different Curing Age.

\begin{tabular}{ll}
\hline Curing Age [Days] [0.50] & Density of Concrete $\left[\mathbf{k g m}^{\mathbf{3}}\right]$ \\
\hline 7 & 2329.71 \\
8 & 2334.03 \\
9 & 2338.37 \\
10 & 2342.71 \\
11 & 2347.06 \\
12 & 2351.42 \\
13 & 2355.77 \\
14 & 2360.16 \\
15 & 2364.55 \\
16 & 2368.94 \\
17 & 2373.34 \\
18 & 2377.74 \\
19 & 2382.16 \\
20 & 2386.58 \\
21 & 2391.02 \\
22 & 2395.46 \\
23 & 2399.9 \\
24 & 2404.36 \\
25 & 2406.42 \\
26 & 2408.83 \\
27 & 2413.3 \\
28 & 2422.27 \\
\hline
\end{tabular}

Table 4. Predictive and Experimental Values for Concrete Density at Different Curing Age.

\begin{tabular}{lll}
\hline $\begin{array}{l}\text { Curing Age } \\
{[\text { Days] [0.50] }}\end{array}$ & $\begin{array}{l}\text { Predictive Values } \\
{\left[\mathbf{k g m}^{\mathbf{3}}\right]}\end{array}$ & $\begin{array}{l}\text { Experimental Values } \\
{\left[\mathbf{k g m}^{\mathbf{3}}\right]}\end{array}$ \\
\hline 7 & 2329.71 & 2325.83 \\
8 & 2334.03 & 2332.67 \\
9 & 2338.37 & 2335.52 \\
10 & 2342.71 & 2344.32 \\
11 & 2347.06 & 2349.21 \\
\hline
\end{tabular}




\begin{tabular}{lll}
\hline $\begin{array}{l}\text { Curing Age } \\
\text { [Days] [0.50] }\end{array}$ & $\begin{array}{l}\text { Predictive Values } \\
{\left[\mathbf{k g m}^{\mathbf{3}}\right]}\end{array}$ & $\begin{array}{l}\text { Experimental Values } \\
{\left[\mathbf{k g m}^{\mathbf{3}}\right]}\end{array}$ \\
\hline 12 & 2351.42 & 2354.09 \\
13 & 2355.77 & 2358.84 \\
14 & 2360.16 & 2363.67 \\
15 & 2364.55 & 2358.51 \\
16 & 2368.94 & 2363.34 \\
17 & 2373.34 & 2378.18 \\
18 & 2377.74 & 2373.01 \\
19 & 2382.16 & 2387.84 \\
20 & 2386.58 & 2382.68 \\
21 & 2391.02 & 2397.51 \\
22 & 2395.46 & 2392.34 \\
23 & 2399.9 & 2387.18 \\
24 & 2404.36 & 2406.02 \\
25 & 2406.42 & 2408.85 \\
26 & 2408.83 & 2405.68 \\
27 & 2413.3 & 2416.51 \\
28 & 2422.27 & 2421.35 \\
\hline
\end{tabular}

\begin{tabular}{lll}
\hline $\begin{array}{l}\text { Curing Age [Days] } \\
{[\mathbf{0 . 5 5}]}\end{array}$ & $\begin{array}{l}\text { Predictive Values } \\
{\left[\mathbf{k g m}^{\mathbf{3}}\right]}\end{array}$ & $\begin{array}{l}\text { Experimental Values } \\
{\left[\mathbf{k g m}^{\mathbf{3}}\right]}\end{array}$ \\
\hline 24 & 2575.4 & 2566.02 \\
25 & 2673 & 2678.85 \\
26 & 2771.47 & 2775.68 \\
27 & 2879.55 & 2876.51 \\
28 & 2444.94 & 2441.85 \\
\hline
\end{tabular}

Table 7. Predictive Values of Concrete Density at Different Curing Age.

\begin{tabular}{ll}
\hline Curing Age [Days] [0.60] & Density of Concrete $\left[\mathbf{k g m}^{3}\right]$ \\
\hline 7 & 1277.92 \\
8 & 1375.37 \\
9 & 1480.24 \\
10 & 1593.58 \\
11 & 1645.32 \\
12 & 1845.58 \\
13 & 1986.03 \\
14 & 1531.56 \\
15 & 1609.56 \\
16 & 1709.54 \\
17 & 1777.68 \\
18 & 1868.21 \\
19 & 1963.35 \\
20 & 2063.34 \\
21 & 1688.77 \\
22 & 1753.23 \\
23 & 1821.28 \\
24 & 1891.39 \\
25 & 1964.18 \\
26 & 2039.79 \\
27 & 2118.31 \\
28 & 2199.84 \\
\hline
\end{tabular}

Table 8. Predictive and Experimental Values for Concrete Density at Different Curing Age.

\begin{tabular}{lll}
\hline $\begin{array}{l}\text { Curing Age } \\
{[\mathbf{0 . 6 0 ]}}\end{array}$ & $\begin{array}{l}\text { Predictive Values } \\
{\left[\mathbf{k g m}^{\mathbf{3}}\right]}\end{array}$ & $\begin{array}{l}\text { Experimental Values } \\
{\left[\mathbf{k g m}^{\mathbf{3}}\right]}\end{array}$ \\
\hline 7 & 1277.92 & 1725.83 \\
8 & 1375.37 & 1882.67 \\
9 & 1480.24 & 2035.52 \\
10 & 1593.58 & 2184.32 \\
11 & 1645.32 & 2349.81 \\
12 & 1845.58 & 2534.99 \\
13 & 1986.03 & 2728.84 \\
14 & 1531.56 & 2083.67 \\
15 & 1609.56 & 2208.81 \\
16 & 1709.54 & 2318.34 \\
17 & 1777.68 & 2428.18 \\
18 & 1868.21 & 2523.01 \\
19 & 1963.35 & 2687.84 \\
20 & 2063.34 & 2812.68 \\
21 & 1688.77 & 2337.51 \\
22 & 1753.23 & 2392.34 \\
23 & 1821.28 & 2387.18 \\
24 & 1891.39 & 2566.02 \\
25 & 1964.18 & 2678.85 \\
26 & 2039.79 & 2775.68 \\
27 & 2118.31 & 2176.51 \\
28 & 2199.84 & 2441.85 \\
\hline
\end{tabular}

Table 9. Predictive Values of Concrete Density at Different Curing Age.

\begin{tabular}{ll}
\hline Curing Age [Days] [0.65] & Density of Concrete $\left[\mathrm{kgm}^{3}\right]$ \\
\hline 7 & 2106.83 \\
8 & 2111.28 \\
9 & 2115.62 \\
10 & 2119.97 \\
\hline
\end{tabular}




\begin{tabular}{ll}
\hline Curing Age [Days] [0.65] & Density of Concrete $\left[\mathbf{k g m}^{\mathbf{3}}\right]$ \\
\hline 11 & 2124.33 \\
12 & 2128.7 \\
13 & 2133.08 \\
14 & 2137.46 \\
15 & 2141.86 \\
16 & 2146.26 \\
17 & 2150.68 \\
18 & 2155.11 \\
19 & 2159.52 \\
20 & 2163.98 \\
21 & 2168.43 \\
22 & 2172.89 \\
23 & 2173.35 \\
24 & 2177.35 \\
25 & 2181.83 \\
26 & 2186.32 \\
27 & 2190.82 \\
28 & 2199.24 \\
\hline
\end{tabular}

Table 10. Predictive and Experimental Values for Concrete Density at Different Curing Age.

\begin{tabular}{lll}
\hline $\begin{array}{l}\text { Curing Age } \\
{[\mathbf{0 . 6 5}] \text { [Days] }}\end{array}$ & $\begin{array}{l}\text { Predictive Values } \\
{\left[\mathbf{k g m}^{3}\right]}\end{array}$ & $\begin{array}{l}\text { Experimental Values } \\
{\left[\mathbf{k g m}^{3}\right]}\end{array}$ \\
\hline 7 & 2106.83 & 2109.83 \\
8 & 2111.28 & 2114.67 \\
9 & 2115.62 & 2119.52 \\
10 & 2119.97 & 2114.35 \\
11 & 2124.33 & 2129.26 \\
12 & 2128.7 & 2124.09 \\
13 & 2133.08 & 2138.84 \\
14 & 2137.46 & 2133.67 \\
15 & 2141.86 & 2144.51 \\
16 & 2146.26 & 2143.34 \\
17 & 2150.68 & 2148.18 \\
18 & 2155.11 & 2153.01 \\
19 & 2159.52 & 2157.84 \\
20 & 2163.98 & 2157.68 \\
21 & 2168.43 & 2167.51 \\
22 & 2172.89 & 2168.34 \\
23 & 2173.35 & 2171.18 \\
24 & 2177.35 & 2178.02 \\
25 & 2181.83 & 2179.85 \\
26 & 2186.32 & 2183.68 \\
27 & 2190.82 & 2186.51 \\
28 & 2199.24 & 2195.35 \\
\hline
\end{tabular}

Table 11. Predictive Values of Concrete Density at Different Curing Age.

\begin{tabular}{ll}
\hline Curing Age [0.70] [Days] & Density of Concrete $\left[\mathbf{K g m}^{3}\right]$ \\
\hline 7 & 1301.59 \\
14 & 1606.4 \\
21 & 1982.62 \\
28 & 2446.92 \\
60 & 2418.62 \\
90 & 2477.13 \\
\hline
\end{tabular}

Table 12. Predictive and Experimental Values for Concrete Density at Different Curing Age.

\begin{tabular}{lll}
\hline $\begin{array}{l}\text { Curing Age [0.70] } \\
{[\text { Days] }}\end{array}$ & $\begin{array}{l}\text { Predictive Values } \\
{\left[\mathbf{K g m}^{3}\right]}\end{array}$ & $\begin{array}{l}\text { Experimental values } \\
{\left[\mathbf{K g m}^{3}\right]}\end{array}$ \\
\hline 7 & 1301.59 & 1277.92 \\
14 & 1606.4 & 1531.56 \\
21 & 1982.62 & 2063.34 \\
28 & 2446.92 & 2421.17 \\
60 & 2418.62 & 2418.62 \\
90 & 2477.13 & 2477.13 \\
\hline
\end{tabular}

Table 13. Predictive Values of Concrete Density at Different Curing Age.

\begin{tabular}{ll}
\hline Curing Age [Days] & Density of Concrete $\left[\mathbf{K g m}^{3}\right]$ \\
\hline 7 & 1849.38 \\
14 & 2205.04 \\
21 & 2421.17 \\
28 & 2572.59 \\
60 & 2542.81 \\
90 & 2604.32 \\
\hline
\end{tabular}

Table 14. Predictive and Experimental Values for Concrete Density at Different Curing Age.

\begin{tabular}{lll}
\hline $\begin{array}{l}\text { Curing Age } \\
\text { [Days] }\end{array}$ & $\begin{array}{l}\text { Predictive Values } \\
{\left[\mathbf{K g m}^{3}\right]}\end{array}$ & $\begin{array}{l}\text { Experimental values } \\
{\left[\mathbf{K g m}^{3}\right]}\end{array}$ \\
\hline 7 & 1849.38 & 1827.92 \\
14 & 2205.04 & 2231.56 \\
21 & 2421.17 & 2413.34 \\
28 & 2572.59 & 2421.17 \\
60 & 2542.81 & 2518.62 \\
90 & 2604.32 & 2577.13 \\
\hline
\end{tabular}

Table 15. Predictive Values of Concrete Density at Different Curing Age.

\begin{tabular}{ll}
\hline Curing Age [Days] & Density of Concrete $\left[\mathrm{Kgm}^{3}\right]$ \\
\hline 7 & 1942.03 \\
14 & 2318.26 \\
21 & 2546.12 \\
28 & 2367.07 \\
60 & 2482.51 \\
90 & 2468.69 \\
\hline
\end{tabular}

Table 16. Predictive and Experimental Values for Concrete Density at Different Curing Age.

\begin{tabular}{lll}
\hline $\begin{array}{l}\text { Curing Age } \\
\text { [Days] }\end{array}$ & $\begin{array}{l}\text { Predictive Values } \\
{\left[\mathbf{K g m}^{3}\right]}\end{array}$ & $\begin{array}{l}\text { Experimental values } \\
{\left[\mathbf{K g m}^{\mathbf{3}}\right]}\end{array}$ \\
\hline 7 & 1942.03 & 1827.92 \\
14 & 2318.26 & 2231.56 \\
21 & 2546.12 & 2413.34 \\
28 & 2367.07 & 2421.17 \\
60 & 2482.51 & 2518.62 \\
90 & 2468.69 & 2577.13 \\
\hline
\end{tabular}

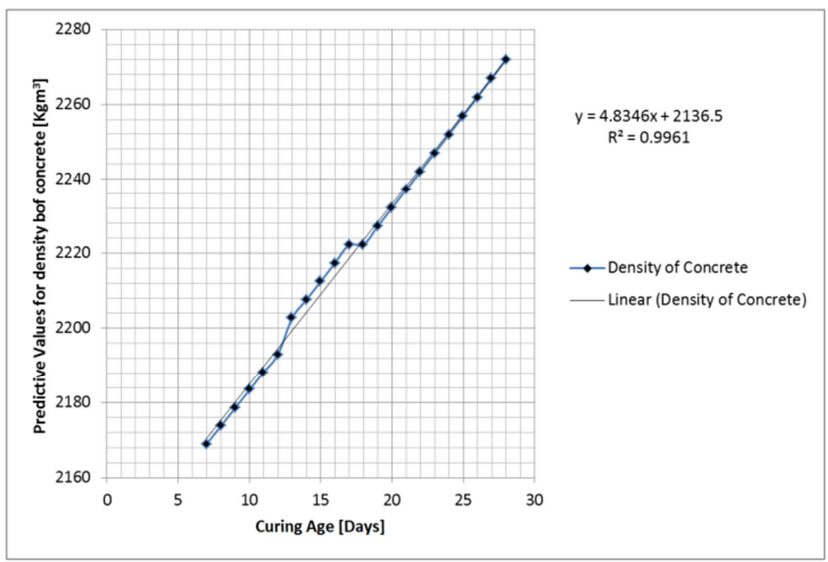

Figure 1. Predictive Value concrete Density at Different Curing Age. 


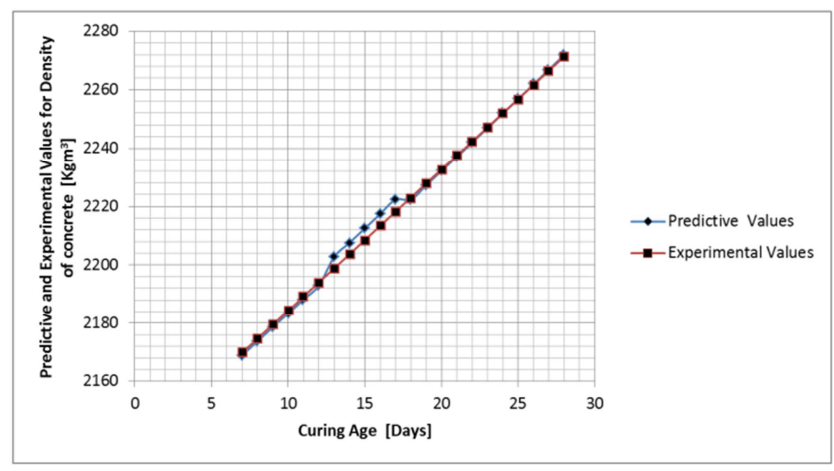

Figure 2. Predictive and Experimental Values for Concrete Density at Different Curing Age.

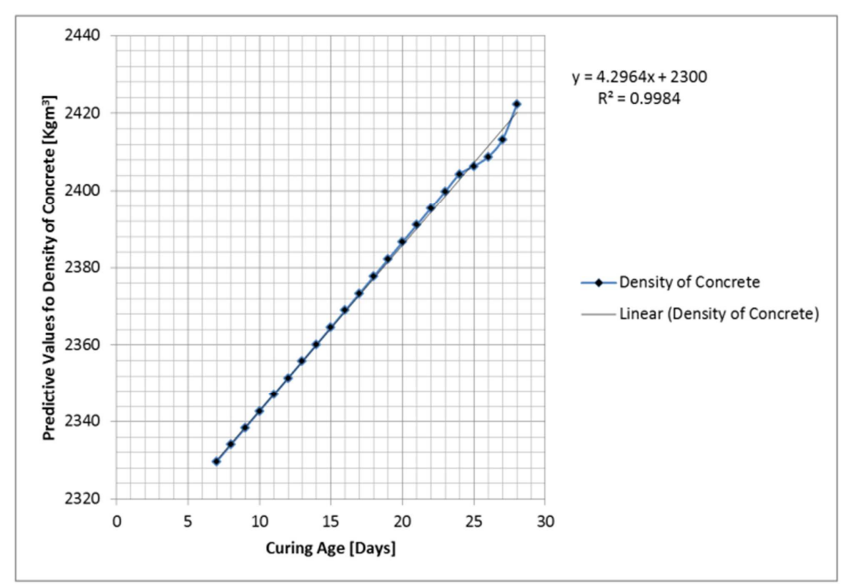

Figure 3. Predictive Value concrete Density at Different Curing Age.

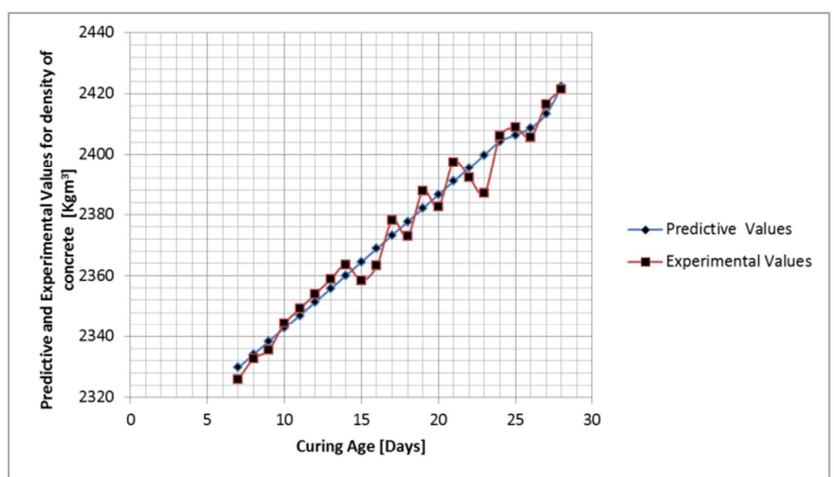

Figure 4. Predictive and Experimental Values for Concrete Density at Different Curing Age.

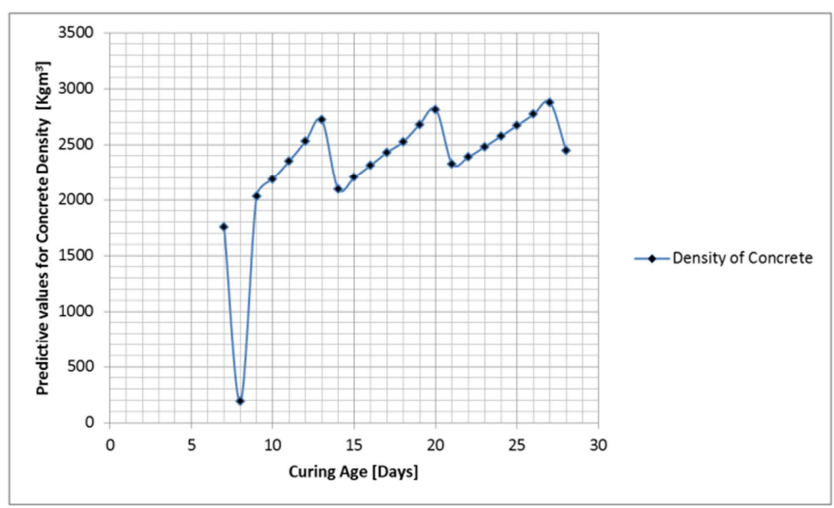

Figure 5. Predictive Values of Concrete Density at Different Curing Age.

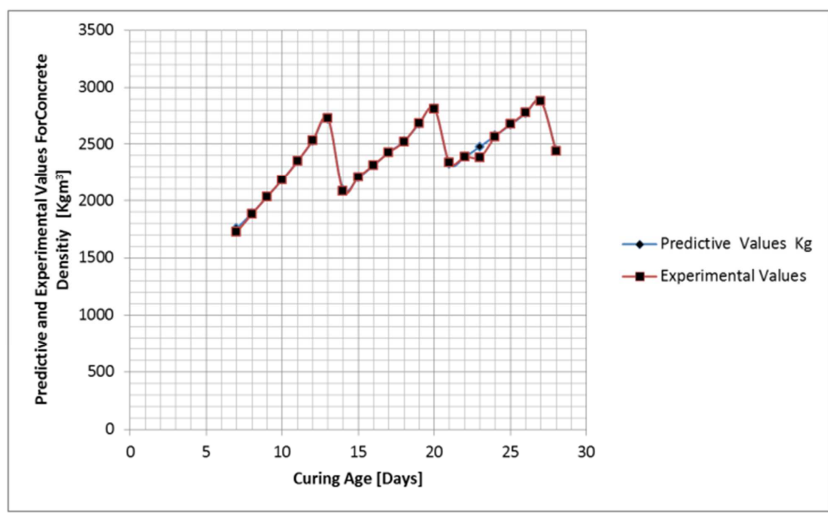

Figure 6. Predictive and Experimental Values for Concrete Density at Different Curing Age.

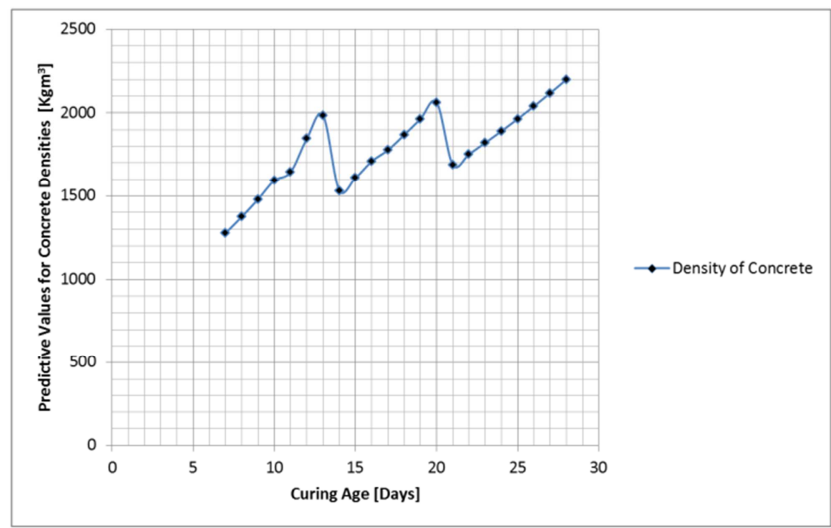

Figure 7. Predictive Values of Concrete Density at Different Curing Age.

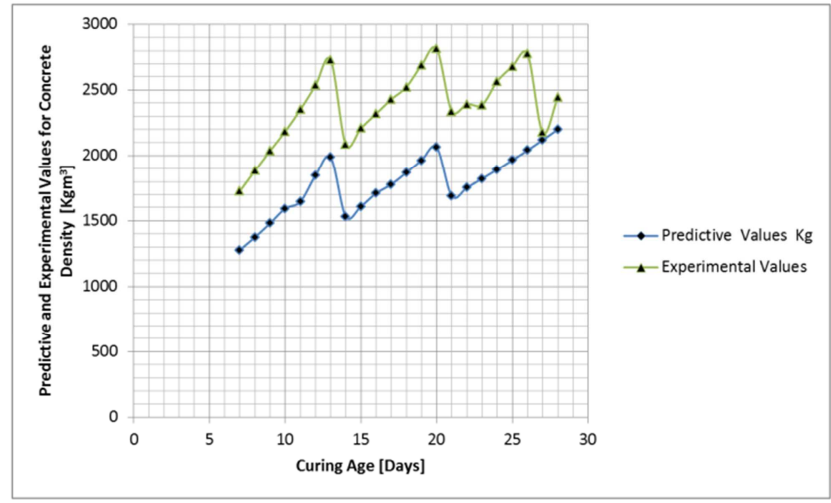

Figure 8. Predictive and Experimental Values for Concrete Density at Different Curing Age.

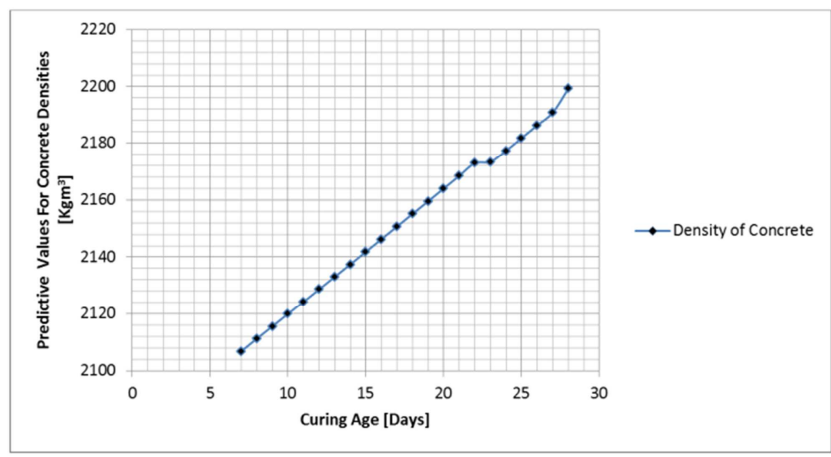

Figure 9. Predictive Values of Concrete Density at Different Curing Age. 


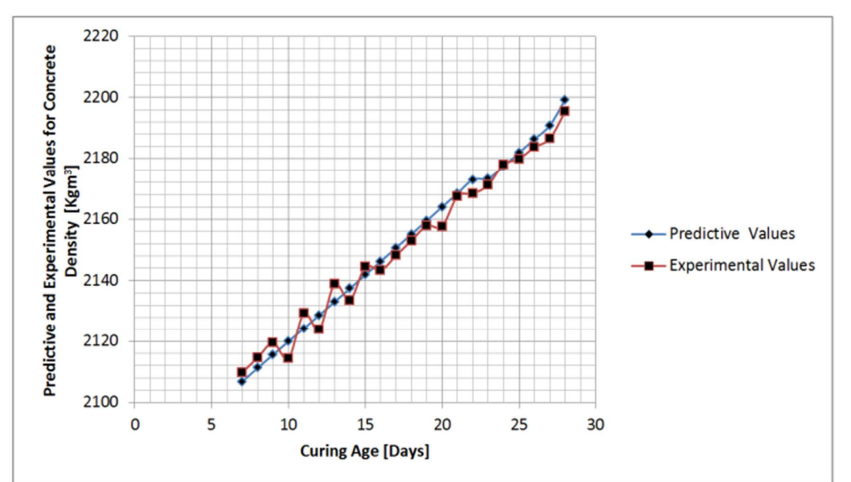

Figure 10. Predictive and Experimental Values for Concrete Density at Different Curing Age.

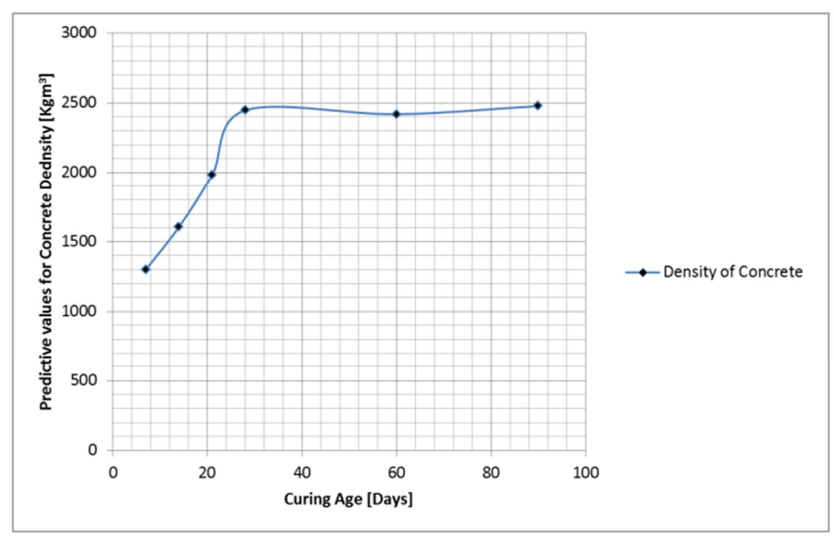

Figure 11. Predictive Values of Concrete Density at Different Curing Age.

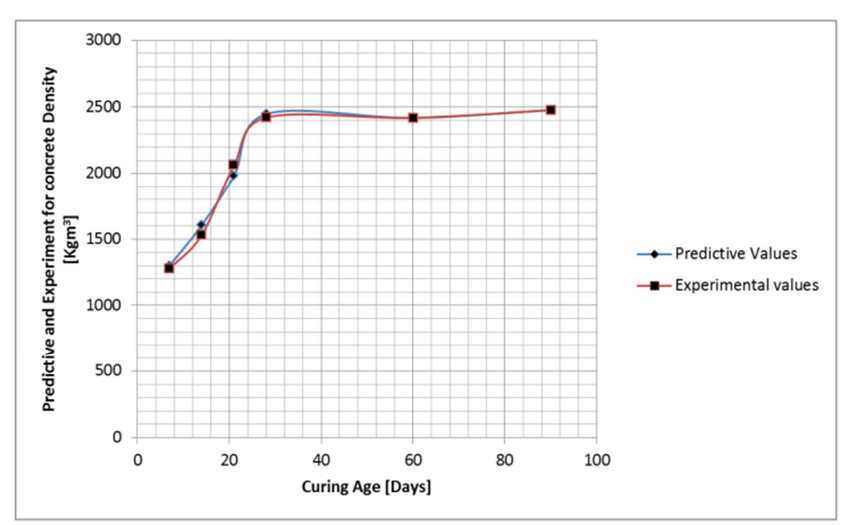

Figure 12. Predictive and Experimental Values for Concrete Density at Different Curing Age.

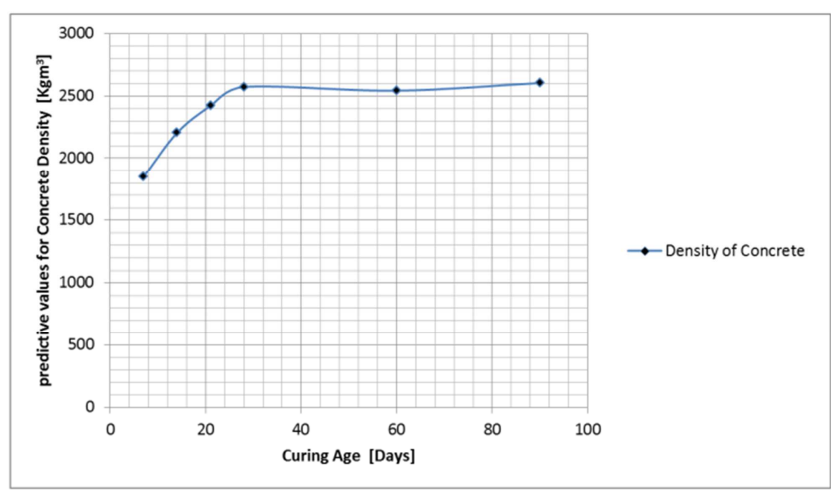

Figure 13. Predictive Values of Concrete Density at Different Curing Age.

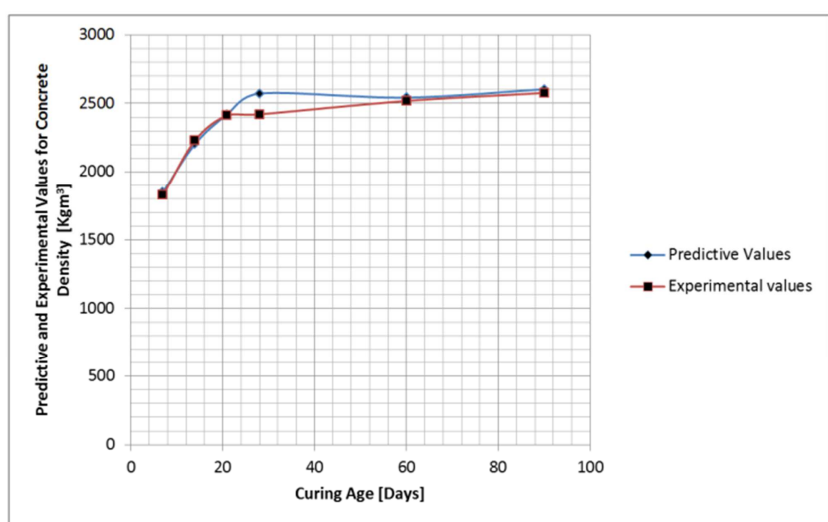

Figure 14. Predictive and Experimental Values for Concrete Density at Different Curing Age.

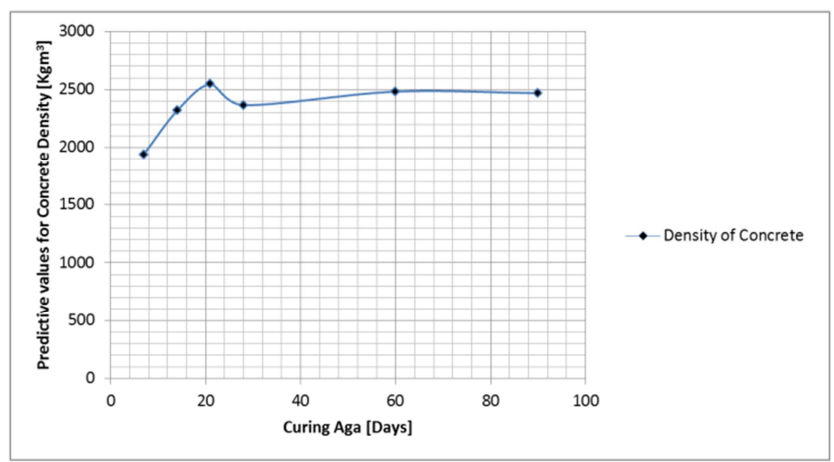

Figure 15. Predictive Values of Concrete Density at Different Curing Age.

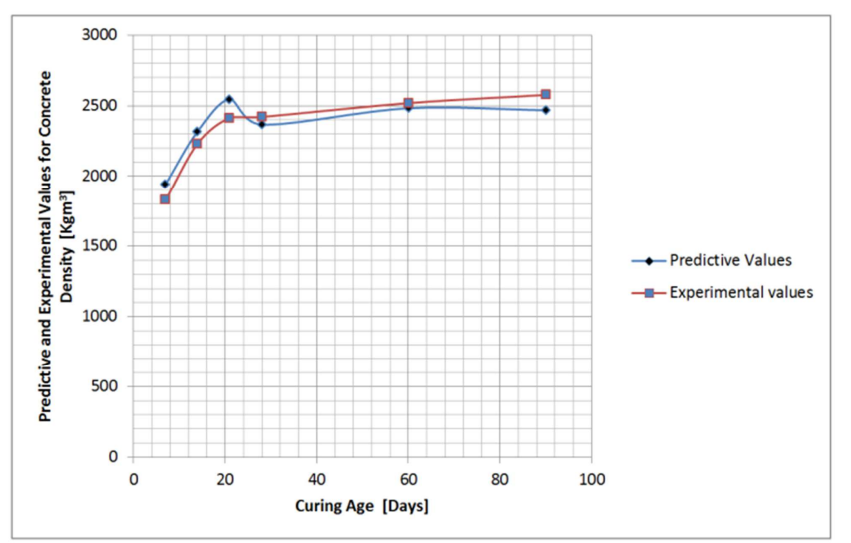

Figure 16. Predictive and Experimental Values for Concrete Density at Different Curing Age.

Concrete densities of different water cement ratios and curing age were express through graphical representation, the study express various influence that has effect on all in one aggregate for higher strength development, these were observed on the process of developing the model that generates predictive values. Figure one express linear increase with slight vacillation to the optimum values recorded at twenty eight days, similar condition were experiences in figure two, gradual increase of density were observed to some point where fluctuation was recorded between thirteen and eighteen days, these continue to the point where the optimum was recorded at twenty eight day with best fits of both parameters. Figure three express similar 
condition like figure one, rapid increase in density were observed with slight fluctuation to the optimum density recorded at twenty eight days, figure four the experimental and predictive were compared to express linear increase at rapid rate with slight vacillation at the optimum values at twenty eight days, but the experiment generated fluctuation from seven to twenty days. Figure five developed fluctuation at every twenty four hours to optimum recorded at twenty seven days declining slight at twenty eight days. Figure six express fitness between the predictive and experimental values, the comparison maintained its fluctuation to the optimum values recorded at twenty seven with slight declined at twenty eight days. Figure seven maintained similar condition like figure five and six, fluctuation were experienced from every twenty four hours to the optimum values at twenty eight days, while figure eight express it increase of density in like manner where the predictive and experimental values developed best fits but the experimental were higher than the predictive vales. Figure nine developed linear increase of concrete density with slight fluctuation between twenty two and twenty five thus linear increases were observed to the optimum values recoded at twenty eight days. Figure ten in the same vein express it fitness between both parameters with slight fluctuation more from the experimental to the optimum values recorded at twenty eight days. Figure eleven express it rate of density at seven days intervals, gradual increase was recorded from seven to twenty eight day thus slight decline at sixty to the optimum values recoded at ninety days. Figure twelve expressions of both parameters was in like manner recorded at eleven, gradual increase was recorded from seven to twenty eight days with slight decline expressing linear increase to the optimum at ninety days, figure thirteen maintained similar condition like that of figure twelve, gradual increase to twenty one with slight decline in linear state to the optimum at ninety days, while figure fourteen maintained best fits between both parameters thus express gradual increase with slight fluctuation to the optimum at ninety days, figure fifteen gradually increase to the optimum values recorded at twenty one day thus developed slight decline in density thus maintaining linear increase to ninety days. Figure sixteen express best fit between predictive and experimental values, the optimum values between the two parameters was recorded at twenty one days, slight decline in density was observed in linear rate to ninety days

\section{Conclusion}

The study has defined the rate of density in concrete formations, the developed model monitored experimental evaluations, expressing through analytical solutions, it produced predicted values for densities. The concept of applying deterministic model is another new developed concept that can be used to predict concrete densities for local occurring $3 / 8$ gravel for higher concrete strength, the developed model can be apply to predict other concrete formations. The developed model express variations in densities, these conditions reflect the variation of mix proportions including variation of concrete porosities. Some lower densities are base on pack distribution on the concrete formations reflecting from compactions variations including higher porosities, these conditions are reflected from lower densities, thus the compressive strength of the concrete. The developed model were compared with experimental values, both parameters express favorable fits, the heterogeneity of the concrete densities has predicted the rate of compressive strength variation, because the rate dense in concrete determined the rate of compressive strength, the prediction of the densities at very twenty four hours in some condition from the developed model has also determined the growth rate of density at every twenty four hours.

\section{Nomenclature}

$\mathrm{C}_{\mathrm{O}}=$ Concrete Density
$\mathrm{W}_{\mathrm{C}}=$ Water Cement Ratio
$\mathrm{N}_{\mathrm{O}}=$ Constant
$\mathrm{S}=$ Stress
$\mathrm{G}=$ specific gravity
$\mathrm{Z}, \mathrm{L}=$ Curing Age

\section{References}

[1] Gopalkrishnan S., Rajmane N. P., Neelamegam M., Peter J. A., and Dattatreya J. K., (2001), Effect of partial replacement of cement with fly ash on the strength and durability of HPC, The Indian Concrete Journal, 75 (5), pp 335-341.

[2] M. S. Shetty (2008). Concrete Technology, S. Chand and Company Ltd., Ramnagar, New Delhi, pp 66-500.

[3] Shridhar R., (2002), Use of chemical admixtures in HPC for durable structures, The Indian Concrete Journal, 76 (9), pp 579-580.

[4] Ramarao G. N., and Seshagiri Rao M. N., (2005), High Performance Concrete Mix Proportioning with Rice Husk Ash as Mineral Admixture, New Building Materials \& Construction World, 10 (7), pp 100-108.

[5] S. P. Shah and S. H. Ahmad (1994), High Performance Concrete: Properties and Applications, Mc-Graw-Hill Inc. Publication, New York.

[6] Popat D. Kumbhar 1, Pranesh B. Murna, 2012 Assessment of suitability of existing mix design methods of normal concrete for designing high performance concrete mixes international journal of civil and structural engineering volume 3 , no 1 .

[7] Ode. T. and Eluozo S. N. 2016 Predictive Model on Compressive Strength of Concrete Made with Locally 3/8 Gravel from Different Water Cement Ratios and Curing Age; International Journal of Scientific and Engineering Research, Volume 7, issue 1 pp 1528-1551.

[8] Ode. T. and Eluozo S. N. - 2016 Model Prediction to Monitor the Rate of Water Absorption of Concrete Pressured by Variation of Time and Water Cement Ratios International Journal of Scientific and Engineering Research, Volume 7, issue 1 pp 1514-1527. 
[9] Ode. T. and Eluozo S. N. 2016 Calibrating the Density of Concrete from Washed and Unwashed Locally 3/8 Gravel Material at Various Curing Age International Journal of Scientific and Engineering Research, Volume 7, issue 1 January-pp 1514-1552-15574.

[10] Ode. T. and Eluozo S. N; 2016 Compressive Strength Calibration of Washed and Unwashed Locally Occurring 3/8 Gravel from Various Water Cement Ratios and Curing Age; International Journal Engineering and General Science Volume 4 Issue 1, pp 462-483.

[11] Ode. T. and Eluozo S. N; 2016 Predictive Model to Monitor Variation of Concrete Density Influenced by Various Grade from Locally $3 / 8$ Gravel at Different Curing Time International Journal Engineering and General Science Volume 4 Issue 1, pp 502-522.

[12] Ode. T. and Eluozo S. N; 2016 Predictive Model to Monitor Vitiation of Stress -Strain Relationship of $3 / 8$ Gravel Concrete with Water Cement Ration [0.45] at Different Load International Journal Engineering and General Science Volume 4 Issue 1, pp 409-418.
[13] Eluozo S. N. and Ode. T. 2015 Modeling and simulation of Compression Strength for Firm Clay in Swampy Area of Ahoada East International Journal of Advance Research in Engineering and Technology Volume 6, Issue 12, pp 73-85.

[14] Eluozo S. N. and Ode. T. 2015 Mathematical Model to Predict Compression Index of Uniform Loose Sand in Coastal Area of Degema, Rivers State of Nigeria International Journal of Advance Research in Engineering and Technology Volume 6, Issue 12, pp 86-103.

[15] Eluozo S. N. and Ode. T. 2015 Mathematical to Monitor Stiff Clay Compression Index in Wet Land Area of Degema International Journal of Advance Research in Engineering and Technology Volume 6, Issue 12, pp 59-72.

[16] Alawode O and. Idowu, O. I. 2011: Effects of Water-Cement Ratios on the Compressive Strength and Workability of Concrete and Lateritic Concrete Mixes. The Pacific Journal of Science and Technology. 